tality. Am J Med 1981;71:363-370.

14. Martino P, Girmenia C, Micozzi A, Raccah R, Gentile G, Venditi M, et al Fungemia in patients with leukemia. Am J Med Sci 1993;306:225-232.

15. Weems JJ Jr. Candida parapsilosis: epidemiology, pathogenicity, clinical manifestations, and antimicrobial susceptibility. Clin Infect Dis 1992;14:756-766.

16. Edwards, JE, Bodey GP, Bowden RA, Büchner T, de Pauw BE, Filler SG et al. International conference for the development of a consensus on the management and prevention of severe candidal infections. Clin Infect Dis 1997;25:43-59.

17. Anaissie E. Opportunistic mycoses in the immunocompromised host experience at a cancer center and review. Clin Infect Dis 1992;14(suppl 1):S43-S53.

18. Eppes SC, Troutman JL, Gutman LT. Outcome of treatment of candidemia in children whose central catheters were removed or retained. Pediatr Infect Dis J 1989;8:99-104.
19. Dato VM, Dajani AS. Candidemia in children with central venous catheters: role of catheter removal and amphotericin B therapy. Pediatr Infect Dis J 1990;9:309-314.

20. Lecciones JA, Lee JW, Navarro EE, Witebsky FG, Marshall D, Steinberg SM, et al. Vascular catheter-associated fungemia in patients with cancer: analysis of 155 episodes. Clin Infect Dis 1992;14:875-883.

21. Nucci M, Silveira MI, Velasco E, Perecmanis T, Martins CA, Spector N, et al. Risk factors for death in cancer patients with fungemia. Clin Infect Dis 1998;27:107-111.

22. Branchini ML, Pfaller MA, Rhine-Chalberg J, Frempong T, Isenberg HD. Genotypic variation and slime production among blood and catheter isolates of Candida parapsilosis. J Clin Microbiol 1994;32:452456.

23. Uzun O, Anaissie EJ. Problems and controversies in the management of hematogenous candidiasis. Clin Infect Dis 1996;22(suppl 2):S95-S101.

\title{
Potential for Cross-Contamination With Needleless Injector
}

\section{Gina Pugliese, RN, MS Martin S. Favero, PhD}

Medical devices that are used on patients in fields containing potentially infectious body fluids can become contaminated and transmit infectious agents to other sites on the patient or to other patients if the devices are not properly cleaned and sterilized or disinfected after each use. One such device is the needleless, or jet, injector, which is used widely in medicine and dentistry to deliver local anesthetic in procedures such as bone marrow aspirations, lumbar punctures, and cutaneous and intraoral injections.

Weintraub and Ponce de Leon from the University of Pennsylvania School of Dental Medicine in Philadelphia conducted a study to determine whether cross-contamination can occur on in vitro reuse of a needleless injector and whether a manufacturer's recommended method of injector decontami-

Yam and colleagues from the Department of Medical Microbiology, Royal Free Hospital School of Medicine, London, have reported recently that extracts of tea (Camellia sinensis) can reverse methicillin resistance in methicillin-resistant Staphylococcus aureus (MRSA) and also, to some extent, penicillin resistance in $\beta$-lactamase-producing $S$ aureus. These phenomena are explained by prevention of PBP2' synthesis and inhibition of secretion of $\beta$-lactamase, respectively. nation (ie, immersion disinfection) is effective in the prevention of cross-contamination. The study was performed with new autoclaved injectors, fluorescein dye, and Streptococcus crista (bacterium commonly found in saliva) in the field of use to determine whether these devices can become contaminated during use and carry over the contamination to other sites during immediate reuse.

Fluorescein dye and bacterial tests with the needleless injectors showed that contamination or carryover does occur. It appeared to be minimized when an autoclaved, sterile rubber cap used over the head of the device during injection was replaced between each use, although replacement of the rubber cap alone did not prevent carryover.

Immersion of the head of the injector in $2 \%$ glutaraldehyde disinfectant solution for 30 minutes followed by a sterile-water rinse and the

\section{Tea for Staphylococcus?}

Synergy between $\beta$-lactams and tea extracts were demonstrated by disc diffusion, checkerboard titration, and growth curves. Partition chromatography of an extract of green tea on Sephadex LH-20 yielded several fractions, one of which contained a virtually pure compound that showed the above-mentioned activities, at concentrations above approximately $2 \mathrm{mg} / \mathrm{L}$. The observed activities are novel and distinct from the previously reported direct antibacter- replacement of the rubber cap with a sterile cap between uses was shown to curtail bacterial growth and prevent cross-contamination on immediate reuse of the device.

The authors concluded that the study demonstrated that needleless injectors become contaminated during in vitro use involving direct contact with contaminated surfaces and that needless injectors carry over the contamination to subsequent sites of release. The replacement of the injector's rubber cap with a new one after initial discharge or the removal of an exposed rubber cap and immersion of the head of the injector in $2 \%$ glutaraldehyde followed by a rinse of the head in sterile water, as recommended by one injector manufacturer, can minimize or eliminate the carryover.

From: Weintraub AM, Ponce de Leon S. Potential for cross-contamination from use of a needleless injector. Am J Infect Control 1998;26:442-445.

ial activity of tea extracts. Prevention of PBP2' synthesis offers possibly an interesting new approach for the treatment of infections caused by MRSA.

From: Yam TS, Hamilton-Miller JM, Shah S. The effect of a component of tea (Camellia sinensis) on methicillin resistance, $\mathrm{PBP} 2$ ' synthesis, and $\beta$-lactamase production in Staphylococcus aureus. J Antimicrob Chemother 1998;42:211-216. 